\title{
Composition, Vigor, and Proteome of Mature Soybean Seeds Developed under High Temperature
}

\author{
C. Ren, K. D. Bilyeu, ${ }^{\star}$ and P. R. Beuselinck
}

\begin{abstract}
The effects of high temperature treatment on soybean [Glycine max (L.) Merr.] seed composition, vigor, and proteome were investigated using mature dry seeds harvested from plants grown in environment-controlled chambers. High day/night temperatures $\left(37 / 30^{\circ} \mathrm{C}\right)$ from stages $\mathrm{R} 5$ through $\mathrm{R} 8$ altered ratios of individual fatty acids to total fatty acid compared to the control $\left(27 / 18^{\circ} \mathrm{C}\right)$. Concentration of sugars decreased, but total protein and phytic acid concentration were unchanged. High temperature resulted in a greater proportion of abnormal seeds, but normal-appearing seed exhibited reduced germination and vigor. Proteomic analysis detected 20 protein identities whose accumulations were changed by the high temperature. Fourteen spots were identified as seven subunits of seed storage proteins. The remaining six proteins were identified as those responding to abiotic stresses or having a function in respiration: (i) sucrose binding protein, (ii) Class III acidic endochitinase, (iii) heat shock protein (HSP22), (iv) late embryo abundant protein, (v) Bowman-Birk proteinase inhibitor, and (vi) formate dehydrogenase. High temperature during seed development changed soybean seed composition and decreased seed vigor, but also changed seed protein expression profiles.
\end{abstract}

Plant Genetics Research Unit, USDA-ARS, Columbia, Missouri and Division of Plant Sciences, Univ. of Missouri at Columbia, Columbia, MO. Contribution of the Missouri Agric. Exp. Stn. Mention of a trademark, vendor, or proprietary product does not constitute a guarantee or warranty of the product by the USDA or the Univ. of Missouri and does not imply its approval to the exclusion of other products or vendors that may also be suitable. Received 7 May 2008. ${ }^{\star}$ Corresponding author (bilyeuk@missouri.edu).

Abbreviations: 2D, two-dimensional; BBI, Bowman-Birk proteinase inhibitor; DIGE, fluorescent difference gel electrophoresis; EM, early methionine-labeled; FDH, formate dehydrogenase; HPLC, high performance liquid chromatography; HSP, heat shock protein; IEF, isoelectric focusing; LEA, late embryogenesis abundant; MALDI-TOF MS, MS/MS, matrix-assisted laser ionization time-of-flight mass spectrometry followed by an additional mass spectrometry analysis; NIR, near infrared; smHSP, low molecular weight heat shock protein; SBP, sucrose binding protein.

$\mathrm{T}$ emperature is an environmental factor that has a considerable influence on plant growth and development. It plays a role in seed development, controlling seed yield, composition, and vigor. High temperature occurs frequently during soybean [Glycine max (L.) Merr.] seed development and maturation, especially in the southern United States. High temperatures during soybean seed development have been reported to have a considerable effect on soybean yields, seed composition, and seed vigor (Dornbos, 1995; Wilson, 2004).

Soybean is a major source of plant protein and oil. Temperature variation has a significant effect on protein and oil synthesis and partitioning in soybean seed (Gibson and Mullen, 1996). Several studies have demonstrated variability in seed protein and

Published in Crop Sci. 49:1010-1022 (2009).

doi: 10.2135/cropsci2008.05.0247

(C) Crop Science Society of America

677 S. Segoe Rd., Madison, WI 53711 USA

All rights reserved. No part of this periodical may be reproduced or transmitted in any form or by any means, electronic or mechanical, including photocopying, recording, or any information storage and retrieval system, without permission in writing from the publisher. Permission for printing and for reprinting the material contained herein has been obtained by the publisher. 
oil composition of soybean exposed to day/night temperature regimes from $15 / 12^{\circ} \mathrm{C}$ to $40 / 30^{\circ} \mathrm{C}$ (Carver et al., 1986; Dornbos and Mullen, 1992; Rebetzke et al., 1996). Soybean produced in the southern regions of the United States exhibits higher protein concentrations than in the northern regions (Breene et al., 1988; Hurburgh et al., 1990). The seed oil concentration in many soybean cultivars has been reported to be positively correlated with temperature conditions where the crop is grown (Keirstead, 1952; Kane et al., 1997). A negative association between seed oil and protein in soybean has been reported (Hymowitz et al., 1972; Burton, 1987; Watanabe and Nagasawa, 1990); however, Piper and Boote (1999) noted that oil and protein both increased with increasing temperature. When soybean seeds develop under elevated temperature, changes occur in seed oil concentration and in the ratios of individual fatty acids to total fatty acids in the oil (Thomas et al., 2003).

Sucrose and the raffinosaccarides raffinose and stachyose are the main reserve carbohydrates of soybean seeds (Abrahamsen and Sudia, 1966). Stachyose, sucrose, and other nonreducing soluble carbohydrates are associated with the onset of desiccation tolerance during seed development and with seed storability (Obendorf et al., 1998). Low-stachyose soybeans have been noted to have germination difficulties (Wilson, 2004). Stachyose is associated with membrane biogenesis during temperature stress by maintaining the integrity of the cell membranes in seeds (Peterbauer et al., 2001). The raffinosaccharides and phytic acid share at least myo-inositol-1-phosphate and possibly free myo-inositol as a common intermediate. Phytic acid refers to the free myoinositol hexakisphosphoric acid and any salt of myo-inositol 1 and isomers 2, 3, 4, 5, and 6 (Loewus, 1990). Phosphorus in seeds is stored primarily in the form of phytic acid (Lott et al., 1995), and low phytic acid soybeans also have been noted to have germination difficulties (Wilson, 2004). Although low stachyose and low phytic acid traits do not appear to be genetically linked, sucrose, raffinose, stachyose, and phytic acid levels in soybean seed have been reported to respond to environmental stresses.

High temperatures during seed development may reduce seed vigor, resulting in poor germination, and uneven seedling establishment has been reported in soybean (Dornbos and Mullen, 1991; Egli et al., 2005; Gibson and Mullen, 1996; Keigley and Mullen, 1986; Spears et al., 1997; TeKrony et al., 2000; Zanakis et al., 1994), common bean (Phaseolus vulgaris L; Abdus and Goodwin, 1980), and canola (Brassica napus L.; Gusta et al., 2004). TeKrony et al. (1996) showed under controlled environmental conditions that temperature above $30^{\circ} \mathrm{C}$ reduced soybean seed vigor. The more days soybean plants were exposed to high temperature, the greater the reduction in seed vigor (Keigley and Mullen, 1986). Long duration of temperatures above $30^{\circ} \mathrm{C}$ occur in many soybean production areas, especially in the Deep South of the United
States. In the Mississippi Valley, for example, an early soybean production system has been adopted to avoid pod abscission due to drought in late July and early August. Soybean yield is stabilized under early soybean production system practices, but the vigor of the resulting seeds is reduced and thought to be caused by high temperatures during seed development.

Studies on high temperature effects on soybean seed composition and vigor at molecular levels are limited, except for FAD2 enzyme (Heppard et al., 1996) and heat shock proteins (HSPs) (Nagao et al., 1995). It has been reported that class III acidic endochitinase (Kasprzewska, 2003), early methioninelabeled (EM) protein (Imai et al., 1996), Bowman-Birk proteinase inhibitor (BBI) (Deshimaru et al., 2004), and formate dehydrogenase (FDH) (Hourton-Cabassa et al., 1998) function when plants encounter abiotic or biotic stresses. Sucrose binding protein (SBP) plays a critical role in sucrose uptake in soybean seed (Grimes et al., 1992).

In this study, we investigated the effects of high temperature on soybean seed composition and vigor and the changes of the proteome in mature dry seeds due to high temperature treatment during seed growth. The potential proteomic basis for the changes in seed composition and vigor as impacted by high temperature is discussed.

\section{MATERIAL AND METHODS Plant Growth and the High Temperature Treatment}

The soybean breeding line N98-4445A (maturity group III) developed for mid-high oleic acid properties (containing $\sim 550 \mathrm{mg}$ oleic acid g ${ }^{-1}$ oil; Burton et al., 2006) was used in our experiment. Forty plants were grown from seed in commercial peat-based growing medium (Premier Horticulture Inc., Quakertown, PA) in 7.6-L plastic pots in Conviron growth chambers (Controlled Environments Ltd., Winnipeg, MB, Canada) at $27 / 18^{\circ} \mathrm{C}$ day/night temperature with a 13.5 -h day photoperiod of $880 \mu \mathrm{mol} \mathrm{m}{ }^{-2} \mathrm{~s}^{-1}$. Plants were watered as necessary and fertilized (Scotts Miracle-Gro Products, Inc., Port Washington, NY) every $2 \mathrm{wk}$. Since soybean seed maturation and storage reserves deposition starts at the reproductive developmental stage R5 (Fehr et al., 1971; Pedersen, 2004), we applied high temperature to the plants from R5 to R8 stages. At R5, 20 plants were chosen at random to remain in the study and the other plants were discarded. Ten plants chosen at random were transferred from $27 / 18^{\circ} \mathrm{C}$ to $37 / 30^{\circ} \mathrm{C}$ with a 13.5 -h day photoperiod of 880 $\mu \mathrm{mol} \mathrm{m} \mathrm{m}^{-2}$. The other 10 plants remained in the $27 / 18^{\circ} \mathrm{C}$ day $/$ night temperature regime. Four growth chambers were utilized to conduct this study as enlarged plant size necessitated that the plants be grown in groups of five plants per growth chamber. At R5 pods with seeds visually determined to be smaller than $8 \mathrm{~mm}$ or larger than $10 \mathrm{~mm}$ were removed from all plants in both temperature regimes to synchronize the developmental stage of seeds when treatment was applied; the number of pods removed was fewer than three pods from each plant on average. Plant arrangement within growth chambers was randomized at each watering to counter any possible positional effects within the chambers. Plants remained in their temperature treatment 
through to maturity (R8). At R8 all pods were hand harvested from each plant and threshed manually, keeping the seed from individual plants separate from seed of other plants. Abnormally shaped or colored seed considered to be atypical for N98-4445A were discarded from seed lots before seed analysis.

\section{Protein and Fatty Acid Determination}

Protein and fatty acid concentrations were determined by near infrared (NIR) spectrometry. Twenty mature dry seeds from each plant were lyophilized, ground into fine powder using a small coffee grinder (SmartGrind CBG5, Black \& Decker Corp., Towson, MD), and stored at $-20^{\circ} \mathrm{C}$. Ground samples for individual plants were scanned by a Foss 3500 NIR spectrophotometer (Foss NIRSystem, Silver Spring, MD). Protein and fatty acid concentrations were generated using calibration models for total nitrogen and fatty acids as described by Roberts et al. (2006), using WinISI software, version 1.02 (Foss, Silver Spring, MD).

\section{Phytic Acid Assay}

Phytic acid of the sampled seeds was assayed using a high performance liquid chromatography (HPLC) technique described by Chen and Li (2003). Phytic acid was extracted from a 25-mg subsample of ground seed as described above with $500 \mu \mathrm{L} 5 \mathrm{M} \mathrm{HCl}$ and shaken for $1 \mathrm{~h}$. Samples were centrifuged at $16,000 \mathrm{~g}$ for $15 \mathrm{~min}$, then the supernatant was passed through a $0.2-\mu \mathrm{m}$ filter and analyzed by HPLC (Agilent Technologies, Chesterfield, MO). The separation was performed by a linear gradient elution program on a Dionex CarboPac PA-100 guard column (50 $\mathrm{mm}$ by $4 \mathrm{~mm}$ ) (Dionex Corp. Sunnyvale, CA) and a CarboPac PA-100 analytical column $(250 \mathrm{~mm}$ by $4 \mathrm{~mm}$, $10 \mu \mathrm{m})$. The gradient elution was effected with a mixture of two eluents: (A) $500 \mathrm{mM} \mathrm{HCl}$ and (B) $\mathrm{H}_{2} \mathrm{O}$; 0 to $16 \mathrm{~min}, 8$ to $20 \% \mathrm{~A}, 92$ to $80 \% \mathrm{~B}$; 16 to $33 \mathrm{~min}, 20$ to $37 \%$ A, 80 to $63 \% \mathrm{~B}$; 33 to $49 \mathrm{~min}, 37$ to $100 \% \mathrm{~A}, 63$ to $0 \% \mathrm{~B}$; 49 to $50 \mathrm{~min}, 100 \% \mathrm{~A}$, $0 \% \mathrm{~B}$; and 50 to $50.1 \mathrm{~min}, 100$ to $8 \% \mathrm{~A}, 0$ to $92 \% \mathrm{~B}$. The peaks were detected by Diode Array detector (G1315B, Agilent Technologies) at $295 \mathrm{~nm}$ after post column derivitization with $\mathrm{Fe}\left(\mathrm{NO}_{3}\right)_{3}\left(1 \mathrm{~g} \mathrm{~L}^{-1}\right.$ in $\left.0.33 \mathrm{M} \mathrm{HClO}_{4}\right)$. The flow rates of the eluent and post-column reaction solution were 1.0 and $0.4 \mathrm{~mL}$ $\mathrm{min}^{-1}$, respectively. The column temperature was maintained at $30^{\circ} \mathrm{C}$. Sodium phytate (Sigma, St. Louis, MO) was used to generate a standard curve.

\section{Sugar Assay}

Oligosaccharides were determined by high performance anion exchange chromatography with pulsed amperometric detection (Bilyeu et al., 2008). An Agilent 1100 series HPLC and an ESA Coulochem III detector (Agilent Technologies) were used. A 12.5-mg subsample of the ground seed as described above was extracted with $0.5 \mathrm{~mL} 50 \%$ ethanol at $70^{\circ} \mathrm{C}$ for $30 \mathrm{~min}$. Samples were then centrifuged at $16,000 \mathrm{~g}$ for $15 \mathrm{~min}$. The supernatant was passed through a $0.2-\mu \mathrm{m}$ filter. Sugars were separated on a Dionex Carbo Pac PA 10 analytical column $(250 \mathrm{~mm}$ by $4 \mathrm{~mm}, 10 \mu \mathrm{m})$ connected to a Carbo Pac PA 10 guard column ( $50 \mathrm{~mm}$ by $4 \mathrm{~mm}$ ). The mobile phase was $90 \mathrm{mM} \mathrm{NaOH}$ with flow rate of $1.5 \mathrm{~mL}$ $\min ^{-1}$, maintained at $30^{\circ} \mathrm{C}$. Detection settings were time $0,0.1 \mathrm{~V}$; time $0.41,-2.0 \mathrm{~V}$; time $0.42,0.6 \mathrm{~V}$; and time $0.44,-0.1 \mathrm{~V}$.

\section{Electric Conductivity Measurement}

Following the method used by Steere et al. (1981), three mature dry seeds from each plant were individually weighed, then each seed was imbibed in $15 \mathrm{~mL}$ of distilled water in a 50-mL polypropylene tube for $60 \mathrm{~min}$. Electric conductivity of the imbibing solution was measured using a conductivity meter and sensor (Mettler-Toledo Inc., Columbus, $\mathrm{OH}$ ). Imbibed seeds were placed in a germination chamber (Cleland International, Rogers, MN) for evaluation of the relationship between its germination ability and conductivity reading. A standard germination procedure was used as outlined by the Association of Official Seed Analysts (2002).

\section{Germination Test}

Two mature dry seeds from each plant within growth chambers were bulked and imbibed and cultured in the dark between two layers of water-saturated paper towel at $25^{\circ} \mathrm{C}$ with standard germination recorded after $7 \mathrm{~d}$ (Association of Official Seed Analysts, 2002). Four replications were tested for the control and high temperature treatments.

\section{Protein Extraction}

Proteins were isolated from a 1-g subsample of the ground seed samples described above, from three randomly chosen plants in both the control and high temperature treatments with phenol extraction and methanol-ammonium acetate precipitation method as described by Mooney and Thelen (2004). Protein concentration was determined using the EZQ Protein Quantitation Kit (Molecular Probes, Inc., Eugene, OR) per manufacturer's instructions.

\section{Two-Dimensional Fluorescent Difference Gel Electrophoresis (DIGE)}

The DIGE technique was used to study the differential protein expression between high temperature treatment and the control, with three biological repeats. The separate protein samples were labeled with spectrally resolvable fluorescent dyes, Cy3 (red) or Cy5 (green) (Amersham Biosciences, Piscataway, $\mathrm{NJ}$ ), in a ratio of $200 \mathrm{pmol}$ of CyDye to $50 \mu \mathrm{g}$ of protein. Protein labeling was achieved by incubation on ice in the dark for $30 \mathrm{~min}$ and the reaction was quenched by adding $1 \mu \mathrm{L}$ of $10 \mathrm{mM}$ lysine, followed by incubation on ice for a further $10 \mathrm{~min}$. Two samples labeled with $\mathrm{Cy} 3$ or $\mathrm{Cy} 5$ for pair comparison were then mixed before isoelectric focusing (IEF). Isoelectric focusing was conducted according to Mooney and Thelen (2004), using 24-cm immobilized $\mathrm{pH}$ gradient strips (linear $\mathrm{pH} 3$ to 10 or $\mathrm{pH} 4$ to 7) (Amersham Bioscience). Strips were passively rehydrated with $100 \mu \mathrm{g}$ of the mixed protein for 12 h. Isoelectric focusing was performed in a Bio-Rad Protean IEF cell (Bio-Rad, Hercules, CA). After IEF, strips were loaded onto an 8 to $16 \%(\mathrm{w} / \mathrm{v})$ acrylamide gradient gel for the second-dimension separation. Second-dimension electrophoresis was performed using an Amersham Biosciences DALT 12 unit. The gel was imaged using the Fujifilm FLA5000 laser image analyzer (Fujifilm Medical Systems USA, Inc., Stamford, CT) and gel images were analyzed using DeCyder DIA software (Amersham Biosciences). 


\section{Two-Dimensional Coomassie Blue Gel Electrophoresis}

Protein spots that had significant differential expression as identified by DIGE were excised from two-dimensional (2D) gels stained by Coomassie Blue to determine the identity of the proteins. Two-dimensional gel electrophoresis was similar to the DIGE method described above with the following differences. The protein samples of $500 \mu \mathrm{g}$ (without labeling with fluorescent dyes) were loaded to each gel, and the gels were stained with Coomassie brilliant blue G-250 (Sigma-Aldrich, St. Louis, MO) immediately after the second-dimension electrophoresis. Gel images were obtained using a GS670 scanning densitometer (Bio-Rad). Protein molecular weight and pI values were estimated from the captured images according to protein molecular mass markers and the $\mathrm{pH}$ gradient using Phoretix 2D software (Nonlinear Dynamics, Newcastle upon Tyne, UK). The spots of interest were excised manually with a $1.5-\mathrm{mm}$ diameter spot picker (The Gel Company, San Francisco, CA).

\section{Trypsin Digestion}

The excised protein spots (plugs) were destained three times with $500 \mu \mathrm{L}$ of $50 / 50(\mathrm{v} / \mathrm{v})$ acetonitrile/100 mM ammonium bicarbonate $(\mathrm{aq})$ for $15 \mathrm{~min}$ each at room temperature with gentle agitation. After a brief rinse with $500 \mu \mathrm{L}$ of acetonitrile, the gel plugs were then dehydrated for $20 \mathrm{~min}$ in a fresh aliquot $(500 \mu \mathrm{L})$ of acetonitrile. After thorough drying, the plugs were rehydrated for $2 \mathrm{~h}$ at $4^{\circ} \mathrm{C}$ in $5 \mu \mathrm{L}$ of a $50 \mu \mathrm{g} \mathrm{mL} \mathrm{m}^{-1}$ solution of Promega modified porcine tosyl-Lphenylalanine chloromethyl ketone-treated porcine trypsin (V511A, specific activity 17,000 units $\mathrm{mg}^{-1}$, Promega, Madison, WI) in $40 \mathrm{mM}$ ammonium bicarbonate/10\% acetonitrile. Proteins were digested in the trypsin solution at $37^{\circ} \mathrm{C}$ overnight. Digestion solutions were removed and the plugs were extracted twice $(10 \mathrm{~min}$ each) with $10 \mu \mathrm{L}$ of 600:300:100 (v/v/v) acetonitrile/water/10\% trifluoroacetic acid with agitation. The two extracts were pooled and $5 \mu \mathrm{L}$ of water was added to each pool to reduce the acetonitrile concentration to less than 50\% (by volume). The pools were frozen with liquid nitrogen and dried on a lyophilizer (Havli et al., 2003; Hellman et al., 1995).

\section{MALDI-TOF MS, MS/MS}

The method followed Medzihradszky et al. (2000). The dried digests were dissolved in $4 \mu \mathrm{L}$ of 700/290/10 (v/v/v) acetonitrile/ water/88\% formic acid for analysis by MALDI-TOF MS. A $0.5-\mu \mathrm{L}$ portion of each sample was mixed with an equal volume of alphacyano-4-hydroxycinnamic acid at $5 \mathrm{mg} \mathrm{mL}^{-1}$ in 500:380:20:100 (v/v/v/v) acetonitrile/water/10\% trifluoroacetic acid (aq)/100 mM (aq) ammonium dihydrogen phosphate. A $0.3-\mu \mathrm{L}$ aliquot of the mixture was deposited on a polished stainless steel target (ABI01192-6-AB; Applied Biosystems, Foster City, CA). Crystallization of the mixture proceeded under ambient conditions. The crystals were not washed (Smirnov et al., 2004).

Spectra for the desalted digests were acquired by using an Applied Biosystems 4700 MALDI TOF/TOF MS (Foster City, CA) with a $355 \mathrm{~nm} \mathrm{Nd:YAG} \mathrm{laser}(200 \mathrm{~Hz})$ in the positive ion delayed extraction reflector MS or MS/MS mode. Parent ion spectra (400 laser shots summed/averaged) were obtained over the mass range 800 to $4000 \mathrm{Da}$. The eight most intense parent ions were automatically selected for MS/MS analysis. Three common trypsin autolysis peptides, 842.51, 870.5412, and 2211.1046 Da were excluded from MS/MS analysis. MS/MS spectra (3000 laser shots) were obtained with the metastable ion suppressor on and using a 1-kV potential difference and room air for collisioninduced dissociation gas (medium pressure). Commercially available peptide standards were used for calibration of the instrument.

\section{Database Search}

Peak lists obtained from the MALDI-TOF MS, MS/MS mass spectra that had been de-isotyped, following baseline correction and noise reduction, were submitted online to Matrix Science's search engines (www.matrixscience.com) against the NCBInr "viridiplantae" protein database (last updated on 25 Aug. 2005). We selected "MS only" search mode to search protein matches first. The search criteria were more stringent for this mode: no missed trypsin cleavages were allowed and the masses of the peptides had to match within 50 ppm of the masses of the tryptic fragments. Masses of eight frequently observed trypsin autolysis peptides were excluded from the search. When no significant matches were obtained by "MS only" search, we extended our search using "MS and MS/MS" mode. The searching criteria for MS and MS/MS mode allowed one missed trypsin cleavage and the permitted mass error for fragment ions was relaxed to 0.1 Da.

\section{Statistical Analysis of Data}

The study was planned as a randomized complete block design with two blocks each comprising two growth chambers. Growth chambers within blocks were each calibrated for the control or high temperature regimes as treatments, providing two replicates of the temperature treatments. Individual plants within each growth chamber were treated as subsamples. Repeated samplings within subsamples were taken; unless otherwise indicated, experimental data were the combined average of three or four sub-subsamplings. ANOVA and $t$ tests (Rosner, 2006) were performed to determine the significant differences $(P<0.05)$ between high temperature and control treatments.

\section{RESULTS}

A large percentage of abnormal seeds (34.6\%) was produced on high temperature-treated plants, compared to $3.7 \%$ on control plants. The abnormal seeds were not uniform in appearance. Many were shriveled with brown and gray discolorations on the seed surface and/or germinated precociously in the pods. The results presented below are for the normal-appearing seed fraction of the seed produced.

\section{Effects of the High Temperature Treatment on Soybean Seed Composition}

The composition of mature dry soybean seeds from high temperature-treated plants and control plants are shown in Table 1. There were no significant differences in total crude protein concentration and phytic acid concentration between seeds produced in the high temperature treatment 
Table 1. Compositional components of soybean seed produced in high vs. control temperatures. Data were the average of four replicates of 20 seeds each.

\begin{tabular}{lccc}
\hline & $\begin{array}{c}\text { High temperature } \\
(\text { mean } \pm \text { SE) }\end{array}$ & $\begin{array}{c}\text { Control } \\
\text { (mean } \pm \text { SE) }\end{array}$ & $t_{\text {test }}{ }^{\dagger}$ \\
\hline Protein & \multicolumn{2}{c}{$\mathrm{mg} \mathrm{g}^{-1}$ seed dry weight } & \\
Palmitic (16:0) & $256 \pm 2.50$ & $438 \pm 2.90$ & $\mathrm{NS}^{\ddagger}$ \\
Stearic (18:0) & $16.1 \pm 0.31$ & $21.2 \pm 0.35$ & $*$ \\
Oleic (18:1) & $83.4 \pm 2.45$ & $11.4 \pm 0.24$ & $*$ \\
Linoleic (18:2) & $75.8 \pm 1.25$ & $78.2 \pm 2.93$ & $*$ \\
Linolenic (18:3) & $1.1 \pm 0.36$ & $5.9 \pm 0.26$ & $*$ \\
Total fatty acid & $197 \pm 1.00$ & $175 \pm 4.80$ & $*$ \\
Sucrose & $54.8 \pm 1.82$ & $59.1 \pm 0.94$ & $\mathrm{NS}$ \\
Raffinose & $14.0 \pm 0.25$ & $14.1 \pm 0.57$ & $\mathrm{NS}$ \\
Stachyose & $40.6 \pm 0.28$ & $43.4 \pm 1.40$ & $\mathrm{NS}$ \\
Combined sugars & $109.4 \pm 1.77$ & $116.6 \pm 1.39$ & $*$ \\
Phytic acid & $20.3 \pm 0.10$ & $20.5 \pm 0.22$ & $\mathrm{NS}$ \\
\hline
\end{tabular}

*Significant at $P<0.05$.

tDifferences between control and high temperature treatments. ‡NS, not significant.

and control. The total fatty acid concentration was 197 $\mathrm{mg} \mathrm{g}^{-1}$ of dry mass of seeds from the high temperature treatment, a significant increase of $12.6 \%$ over the control (Table 1). Concentrations of each fatty acid also changed in response to the high temperature treatment. The concentrations of palmitic (16:0), stearic (18:0), and oleic (18:1) acids in mature seeds increased significantly by 18,41 , and $44 \%$, respectively, over the control, while the concentrations of linoleic (18:2) and linolenic (18:3) acids decreased significantly by 3 and $81 \%$, respectively (Table 1 ).

Concentrations of sucrose, raffinose and stachyose of seeds from high temperature-treated plants were not significantly different from those of seeds of control plants. However, when the three sugars were summed for each seed sample, the sugar concentration of seeds from the high temperature treatment were significantly lower than the seeds of the control by $6.2 \%$ (Table 1 ).

\section{Effects of the High Temperature Treatment on Soybean Seed Vigor}

Normal-appearing seeds from the high temperature regime weighed an average of $15.3 \mathrm{mg} \mathrm{seed}^{-1}$ compared to $21.7 \mathrm{mg} \mathrm{seed}^{-1}$ for plants grown in the control temperature regime (Table 2). The electrical conductivity of the post-soak imbibing solution was significantly greater for seeds of plants receiving the high temperature treatment than seeds from control plants (Table 2). The percentage of germination of seeds developed in the high temperature treatment was less than half that of seeds from control plants (Table 2). Surface color of many normal-appearing seeds from the high temperature treatment became discolored from buff to brown after a few days in the germination conditions then deteriorated without germinating.
Proteomic Study on the Effects by Heat Stress

Protein samples extracted from embryos of seeds developed in the high temperature treatment or from embryos of seeds from the control temperature were labeled with either Cy3 or Cy5 florescent dyes, equally pooled, and loaded onto 2D gels. Among 1300 to 1500 protein spots shown in each of three DIGE gels of biological replicates, 20 spots with an average volume ratio (high temperature treated/control, or vice versa) no less than 1.5 were selected (Fig. 1 and 2; Table 3) for analysis by MALDITOF MS, MS/MS. Among the 20 spots, there were seven protein spots with volumes decreased by high temperature treatment and 13 spots with increased volumes (Table 3). Fifteen of the 20 protein spots analyzed by MALDI-TOF MS, MS/MS were significantly matched to known protein identities after subjected to database search using the MS only mode (or Peptide Mass Fingerprint mode). The remaining five spots (spot numbers 2, 10, 15, 19, and 20) were identified as significant matches (Table 4) after being searched with the "Combined MS plus MS/MS" mode.

Among the 20 proteins identified, 14 protein spots represented seven subunits of the storage proteins $11 \mathrm{~S}$ glycinin or 7S $\beta$-conglycinin. Protein spots 3 and 13 were $\beta$ subunits of $\beta$-conglycinin homotrimer; the spots $4,5,6,7,17$, and 18 represented the precursor of the A1ab1b subunit of glycinin; while the spots 8 and 9 represented the Gly4 (A5A4B3) subunit of glycinin. The spots 11, 12, 14, and 16 were four other different subunits of glycinin or conglycinin. It has been suggested that a protein might be distributed as multiple spots with different pIs and molecular masses in a $2 \mathrm{D}$ gel due to post-translational modification of the proteins (Wan et al., 2005), and this has been specifically observed among soybean storage proteins (Mooney and Thelen, 2004).

The other 6 of the 20 protein spots analyzed were identified as having known functions. Four of the proteins, FDH, Class III acidic endochitinase, HSP22, and EM protein, have been reported as responding to abiotic stress. Among the four proteins only HSP22, a small molecular mass HSP, was reported to be induced by high temperature stress. The protein FDH has a function in respiration (Tishkov and Popov, 2004). The final two proteins of the 20 protein spots analyzed were identified as an SBP and a Bowman-Birk type proteinase inhibitor D.

\section{DISCUSSION}

This study has shown that the high temperature treatment $\left(37 / 30^{\circ} \mathrm{C}\right.$, day/night) from R 5 to R 8 stages of seed development significantly altered the composition of the mature soybean seed as compared to those from the control temperature treatment $\left(27 / 18^{\circ} \mathrm{C}\right)$. Seed development under the high temperature regime significantly increased the total oil (represented as total fatty acid) concentration and the concentrations of palmitic (16:0), stearic (18:0), and oleic (18:1) acids, while the concentrations of linoleic (18:2) and 
linolenic (18:3) acids decreased. The combined concentration of sucrose, raffinose, and stachyose significantly decreased in response to the high temperature regime, although individually their concentrations did not significantly differ from those obtained from seed of plants grown in the control temperature regime. The high temperature regime did not significantly change the concentrations of total protein and phytic acid over concentrations obtained from seed of plants grown in the control temperature regime (Table 1). In general, it has been reported that soybean seeds developed under higher temperatures have higher oil concentrations and that there is an inverse relationship between seed oil and protein (Piper and Boote, 1999; Wilson, 2004; Wolf et al., 1982). However, one cannot assume that all soybean cultivars respond to temperature in the same manner. Thomas et al. (2003) reported an increase in both seed protein and oil concentrations when soybean was grown in elevated temperatures as high as $40 / 30^{\circ} \mathrm{C}$ (day/night). While in a 2 -yr experiment with drought and high air temperature, Dornbos and Mullen (1992) reported that oil contents were reduced slightly only in $1 \mathrm{yr}$ by high temperature $\left(33\right.$ and $\left.35^{\circ} \mathrm{C}\right)$, while protein content increased in both years; drought stress exacerbated oil content decrease by a large margin, accompanied by a $70 \%$ reduction in yield and an increase in seeds that were flattened and discolored. The discrepancy in the changes of protein and oil concentrations among different reports could reflect the use of different cultivars or environmental conditions (high temperature with or without drought) applied.

An increase in percent protein and decrease in percent oil resulting from depodding has been reported (McAlister and Krober, 1958; Openshaw et al., 1979). However, moderate depodding has only a slight effect on seed composition (McAlister and Krober, 1958; Miceli et al., 1995). We enacted a minor level of depodding at R 5 that might have affected the composition of seed harvested at R8. We cannot determine to what extent the depodding in this study altered the seed composition we observed, but it may be minor. N98-4445A was developed to produce an elevated oleic acid concentration and the level we observed in the control treatment (Table 1) falls within the concentration range Burton et al. (2006) observed for this line when grown in eight field locations in 2003; they did not report protein levels.

High temperature has been reported to alter seed total oil concentrations and ratios of oleic, linolenic, and linolenic acids to total fatty acids in soybean (Wilson, 2004) and in sunflower (Helianthus annuus L.) (Fernandez-Moya et al., 2003); our observations support those findings. The relationship between temperature and fatty acid ratios may be explained by the sensitivity of $\omega-6$ desaturase, the enzyme that converts the fatty acids $18: 1$ to $18: 2$, to temperature changes and accounts for an increased oleic acid ratio, relative to total fatty acids, under high temperature growing conditions (Wilson, 2004).

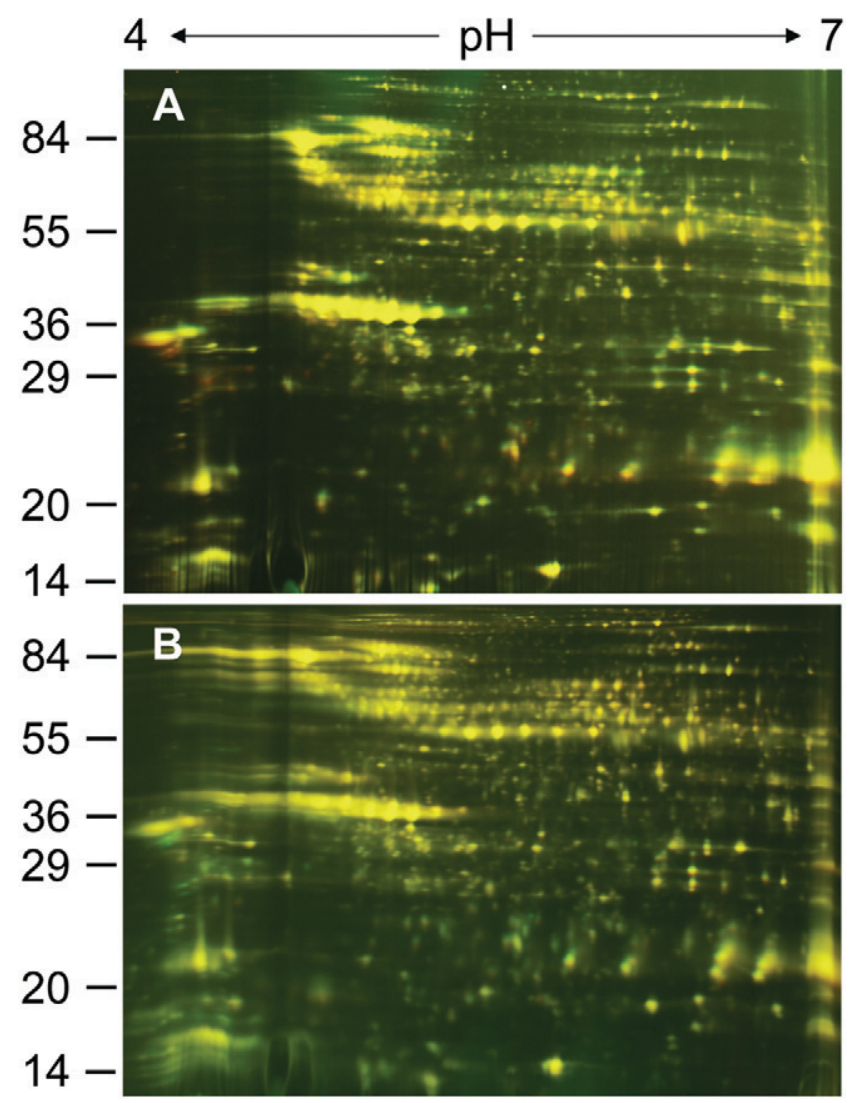

Figure 1. Analytical two-dimensional fluorescent difference gel electrophoresis maps of mature soybean embryo proteins from plants grown with or without high temperature treatment. (A) image of samples from the high temperature treatment (labeled with Cy5) and from the control temperature treatment (labeled with Cy3). (B) Biological repeat image of image A, with Cy3-labeled sample from the high temperature treatment and Cy5-labeled sample from the control temperature treatment. Fifty micrograms of each labeled protein sample was pooled and resolved in $\mathrm{pH} 4$ to 7 linear immobilized pH gradient strip followed by 11 to $17 \%$ gradient sodium dodecyl sulfate polyacrylamide gel electrophoresis. The molecular masses $(\mathrm{kDa})$ of marker proteins are indicated on the left of $A$ and $B$, and $\mathrm{pl}$ values on the edge of the gel are indicated on the top of $A$. 


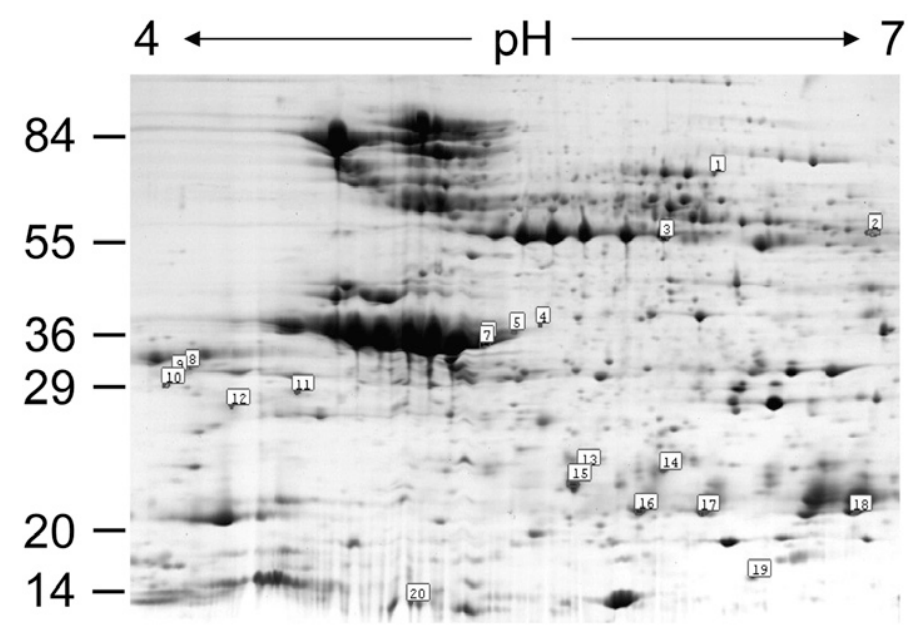

Figure 2. Coomassie Blue-stained two-dimensional map of mature soybean embryo proteins Each $250 \mu \mathrm{g}$ of extracted protein from samples from the control and high temperature treatments were pooled (500 $\mu \mathrm{g}$ in total) and resolved in $\mathrm{pH} 4$ to 7 linear immobilized $\mathrm{pH}$ gradient strip followed by 11 to $17 \%$ gradient sodium dodecyl sulfate polyacrylamide gel electrophoresis. Mass ranges (kDa) and $\mathrm{pl}$ are noted. The 20 protein spots for spot excision were chosen manually based on the differential display in the fluorescent difference gel electrophoresis gels with volume ratio $\geq 1.5$ (Table 1).
The changes in fatty acid ratios are not only reflected in seed storage oil, but also in the membrane phospholipids of plant tissues and organelles (Davy de Virville et al., 2002; Sinensky, 1974). Dornbos et al. (1989) reported that the fatty acid composition of each phospholipid class was altered by drought and high temperature stress. In soybean seeds developed and matured under high temperature and severe drought stress, increased ratios of 16:0 and 18:0 fatty acids and decreased ratios of 18:2 and 18:3 fatty acids were present in phosphatidylcholine and phosphatidylethanolamine that composed $89 \%$ of the isolated phospholipids; while more 18:3 and less 16:0 fatty acids were present in phosphatidylinositol. Those changes were comparable to those of the triglyceride (storage oil) in the same seeds. In addition, the elevated temperature increased the proportion of phosphatidylcholine and phosphatidylinositol and decreased that of phosphatidylethanolamine (Dornbos et al., 1989). The effect of drought and high temperature stress on phospholipid class has important implications on the ability of the seed to maintain optimum rates of metabolism in seed development and germination (Dornbos et al., 1989).

Our research has shown that seed development during high temperature growth conditions reduced soybean seed vigor, relative to cooler temperature growth conditions (Table 2). It has been reported that high temperature stress during soybean seed development can reduce seed size and yield and increase the proportion of abnormal seeds (Baker et al., 1989; Dornbos and Mullen, 1991; Egli and Wardlaw, 1980; Gibson and Mullen, 1996; Spears et al., 1997; Zanakis et al., 1994). Spears et al. (2005) reported that as temperatures increased during seed filling of high-oleate soybean seed, germination decreased and even moderate temperatures during seed development adversely influenced seed quality. Egli et al. (2005) also reported that reduced seed vigor and germination were concomitant with mean daily maximum temperature increases encountered in field-grown soybean, but the relationship between germination and the temperature varied among cultivars. Although the germination of some cultivars appear tolerant to high temperatures encountered during seed development, lowered seed quality is apparent in accelerated aging tests (Egli et al., 2005). High temperature during seed development decreased the germination of affected seeds more for plants grown in environment-controlled chambers versus field-grown plants. Temperatures regimes reported to be detrimental to soybean germination range between 33 to $38^{\circ} \mathrm{C}$ days and 27 to $35^{\circ} \mathrm{C}$ nights (Keigley and Mullen, 
Table 4. Protein identified by MALDI-TOF-MS, MS-MS mass spectra followed by data searching against the NCBInr "viridiplantae" protein database using Matrix Science's search engines. ${ }^{\dagger}$

\begin{tabular}{|c|c|c|c|c|c|c|}
\hline $\begin{array}{l}\text { Spot } \\
\text { no. }\end{array}$ & $\begin{array}{l}\text { Mowse } \\
\text { score }\end{array}$ & $\begin{array}{c}\text { Theoretical } \\
\text { mass }\end{array}$ & Theoretical pl & $\begin{array}{l}\text { Sequence } \\
\text { coverage }\end{array}$ & $\begin{array}{l}\text { GenBank } \\
\text { accession }\end{array}$ & Protein§ \\
\hline & & $\mathrm{kDa}$ & & $\%$ & & \\
\hline 1 & 208 & 60.9 & 6.42 & 50 & Q04672 & SBP precursor (Glycine max) \\
\hline 2 & 50,76 & 41.7 & 6.9 & 22 & Q9ZRI8 & Mitochondrial NAD-dependent FDH \\
\hline 3 & 231 & 47.9 & 5.67 & 67 & $1 \mathrm{IPJC}$ & $\beta$-conglycinin $\beta$ subunit homotrimer (G. max) \\
\hline 4 & 82 & 54.0 & 5.78 & 18 & $1 F X Z C$ & Glycinin A1ab1b subunit precursor (G. max) \\
\hline 5 & 159 & 54.0 & 5.78 & 43 & $1 F X Z C$ & Glycinin A1ab1b subunit precursor (G. max) \\
\hline 6 & 148 & 54.0 & 5.78 & 43 & $1 F X Z C$ & Glycinin A1ab1b subunit precursor (G. max) \\
\hline 7 & 144 & 54.0 & 5.78 & 49 & $1 F X Z C$ & Glycinin A1ab1b subunit precursor (G. max) \\
\hline 8 & 128 & 24.3 & 4.46 & 72 & CAB57802 & Glycinin Gly4 (A5A4B3) subunit (G. max) \\
\hline 9 & 128 & 24.3 & 4.46 & 72 & CAB57802 & Glycinin Gly4 (A5A4B3) subunit (G. max) \\
\hline 10 & 34,264 & 37.5 & 4.96 & 15 & BAA25015 & Class III acidic endochitinase (G. max) \\
\hline 11 & 88 & 63.2 & 4.92 & 25 & BAA23360 & $\beta$-conglycinin $\alpha$ subunit (G. max) \\
\hline 12 & 83 & 45.0 & 5.62 & 35 & AAO45103 & $\beta$-conglycinin $\alpha^{\prime}$ subunit (G. max) \\
\hline 13 & 114 & 47.9 & 5.67 & 37 & 1IPJC & $\beta$-conglycinin $\beta$ subunit homotrimer (G. max) \\
\hline 14 & 168 & 55.9 & 5.46 & 24 & 10D5B & Glycinin A3B4 subunit homohexamer (G. max) \\
\hline 15 & 58,227 & 20.6 & 5.47 & 48 & CAA30168 & $\operatorname{HSP} 22($ G. max) \\
\hline 16 & 103 & 25.1 & 5.50 & 66 & AAA33963 & Glycinin A2B1a subunit precursor (G. max) \\
\hline 17 & 86 & 54.0 & 5.78 & 34 & $1 F X Z C$ & Glycinin A1ab1b subunit precursor (G. max) \\
\hline 18 & 87 & 54.0 & 5.78 & 32 & $1 F X Z C$ & Glycinin A1ab1b subunit precursor (G. max) \\
\hline 19 & 36,84 & 11.5 & 5.52 & 11 & AAB71224 & EM protein (G. max) \\
\hline 20 & 50,80 & 12.3 & 4.98 & 31 & CAA48658 & Bowman-Birk type proteinase inhibitor D (G. max) \\
\hline
\end{tabular}

†MALDI-TOF MS, MS/MS, matrix-assisted laser ionization time-of-flight mass spectrometry followed by an additional mass spectrometry analysis.

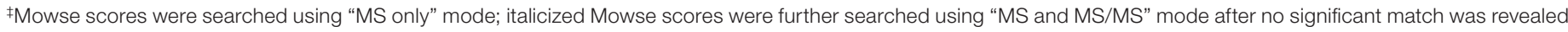
by "MS only" mode.

§SBP, sucrose binding protein; FDH, formate dehydrogenase; HSP, heat shock protein; EM, early methionine-labeled.

1986; Dornbos and Mullen, 1991; Gibson and Mullen, 1996; Spears et al., 1997; TeKrony et al., 2000; Egli et al., 2005). Reduced germination of seeds produced during high temperature growing conditions has been also reported for canola (Brassica napus L.; Gusta et al., 2004), bean (Phaseolus vulgaris L.; Abdus and Goodwin, 1980) and peanut (Arachis hypogaea L.; Spears et al., 2005).

The reduced seed vigor could be partially explained by the changes in fatty acid composition of the cellular membrane phospholipids. During periods of high temperature stresses the stability of cellular membranes is crucial to developing seeds. High temperatures modify the fatty acid composition of phospholipids, resulting in the changes in fluidity of membrane lipids and the combination of integral membrane proteins and lipids, which lead to changes of membrane configuration or structure and leakage of ions and loss of function (Taiz and Zeiger, 1998). Electric conductivity has been used to determine ion leakage for evaluating the extent of membrane damage and function loss (Association of Official Seed Analysts, 2002) and has been applied to soybean seed vigor tests, as complementary to germination tests (Colete et al., 2004; Egli and TeKrony, 1995; Vieira et al., 1999). Two methods have been reported for electrical conductivity measurement: bulk seed conductivity and single seed conductivity. The former test predicts seed vigor of a bulk of seed (Association of Official Seed Analysts, 2002) and the latter predicts vigor of a single tested seed (Steere et al., 1981). Hamman et al. (2001) reported that the single soybean seed conductivity test did not accurately predict seedling performance in any of their experiments. We tested the electrical conductivity of 30 single seeds developed under the high temperature regime and 30 single seeds developed under the control regime. No statistically significant association was found between conductivity and germination (data not shown). When the electrical conductivity responses of 30 single seeds were averaged within treatments, seeds that developed under the high temperature treatment had a higher electrical conductivity $(P<0.05)$ than seeds that developed under the control treatment (Table 2).

The decrease of sucrose, raffinose, or stachyose under high temperature was not significant at $P<0.05$, but at $P<0.10$ the decreases of sucrose and stachyose were significant. High-temperature stress inhibits photosynthesis and the production of sucrose (Taiz and Zeiger, 1998). Sucrose is the major form of carbon for transportation from source to sink in plants. We observed that soybean seeds that developed under the high temperature treatment were lower in sucrose, had less SBP, and were smaller in size (Table 1), implying that the high temperature treatment inhibited 
synthesis of sucrose and SBP, resulting in small seed and reduced yield. Raffinose and stachyose are the two main $\alpha$-linked oligosaccharides in soybean seed and are indigestible by animals and humans (Lowell and Kuo, 1989). Though the biological functions of raffinose and stachyose are not clear, it has been reported that soybean seed with low stachyose levels germinate poorly (Wilson, 2004). The lower stachyose content of seeds developed under the high temperature regime, relative to seeds developed under the control temperature regime, might partially explain the low germination we observed. The lower germination we observed was not associated to phytic acid level because there was no difference in phytic acid between seeds from the control and high temperature.

No significant change in total seed protein concentration was detected when the seed developed under high temperature conditions (Table 1). However, we identified 20 protein spots in mature dry seeds developed under the high temperature regime that decreased or increased by at least 1.5 times, relative to seeds that developed under the control temperature regime. Among the 20 spots, 14 spots were identified as seven subunits of soybean seed storage proteins $11 \mathrm{~S}$ glycinin or $7 \mathrm{~S} \beta$-conglycinin glycine (Table 4). Storage proteins account for the majority of the proteins in soybean seeds and $11 \mathrm{~S}$ glycinin and $7 \mathrm{~S} \beta$-conglycinin are the major storage proteins accounting for 37.7 to $88.2 \%$ of the total seed protein with a mean of $63 \pm 13.2 \%$, depending on the cultivar (Medeiros, 1982). Glycinin is a hexamer composed of nonidentical subunits. Each of the subunits identified so far are encoded by one of five structural genes. The initial translation product of these genes is a proglycinin precursor that is modified post-translationally as it undergoes maturation and assembly. When mature, each subunit consists of an acidic polypeptide chain and a basic chain linked via a disulfide bond, and both acidic and basic polypeptides in a subunit are from a common precursor (Nielsen and Nam, 1999). The storage protein $\beta$-conglycinin also has six isoforms and each isoform consists of different combinations of three main types of subunits designated $\alpha, \alpha^{\prime}$, and $\beta$ (Nielsen and Nam, 1999). We observed that expression levels of $\alpha, \alpha^{\prime}$, and $\beta$ subunits of $\beta$-conglycinin, $A 1 \mathrm{aB} 1 \mathrm{~b}$, $\mathrm{A} 2 \mathrm{~B} 1 \mathrm{a}, \mathrm{A} 3 \mathrm{~B} 4$, and $\mathrm{A} 5 \mathrm{~A} 4 \mathrm{~B} 3$ subunits of glycinin (i.e., all the subunits except for A1bBla) were altered in seeds developed under the high temperature treatment relative to seeds developed under the control temperature treatment (Tables 4). Some changes in storage protein occurred during posttranslational modification. For example, the amount of glycinin A1ab1b polypeptide decreased at spots 4 to 7 (gel mass 32.2 to $30.2 \mathrm{kDa}$, and gel $\mathrm{pI} 5.4$ to 5.2 ), but increased at spots 17 and 18 (gel mass $18.5 \mathrm{kDa}$, and gel pI 6.0 to 6.5). A similar change was found in the $\beta$ subunit of $\beta$-conglycinin that decreased at spot 3 , but increased at spot 13 . This experiment demonstrated that the high temperature during soybean seed production changes the balance of each subunit of the seed storage protein glycinin and $\beta$-conglycinin, although the total protein concentration stays the same. Other reports on the subunit changes soybean storage proteins, as affected by high temperature, were not found.

A decrease in the amount of an SBP precursor was observed in seeds developed under the high temperature treatment, relative to the control temperature. The SBP is associated with plasma membranes and is a vehicle for sucrose transport across the plasma membrane. The accumulation pattern of SBP closely parallels the rate of sucrose uptake in soybean cotyledons (Grimes et al., 1992). Soybean seed that developed under the high temperature treatment was smaller and the sucrose content was lower than seed that developed under the control temperature treatment (Tables 1 and 2). This is additional evidence to support our contention that high temperature inhibited the synthesis of SBP of seed developing under our experimental temperature regime, and the lower volume of SBP may have inhibited the transport of sucrose resulting in smaller mature seed.

Seeds that developed under the high temperature treatment produced less FDH compared to seed that developed under the control temperature treatment. Formate dehydrogenase plays a crucial role in providing $\mathrm{NADH}$ to the respiratory chain. In higher plants, FDH (EC 1.2.1.2.) is an $\mathrm{NAD}^{+}$-dependent enzyme located in mitochondrial matrices and catalyzes oxidation of formate ion to carbon dioxide, which is coupled to the reduction of $\mathrm{NAD}^{+}$to NADH (Tishkov and Popov, 2004) and synthesis of ATP (Oliver, 1981). It has been reported that the amount of FDH transcripts and proteins are positively associated to environmental stresses, such as cold, drought, and dark (Hourton-Cabassa et al., 1998), but no relationships between FDH accumulation and high temperature stress have been reported. The reduction of FDH in seeds developed under the high temperature treatment relative to seeds from the control temperature regime might partially explain the reduced seed vigor we observed. We assume that lower FDH levels result in reduced respiration and production of $\mathrm{NADH}$ in mitochondria, causing reduced seed and seedling vigor.

Class III acidic endochitinase increased in seeds developed under the high temperature treatment relative to seeds from the control temperature regime. Class III acidic endochitinase, one of the chitinases, was isolated first from soybean seeds (Yeboah et al., 1998). Chitinase [EC 3.2.1.14] catalyzes the hydrolysis of $\beta-1,4$ linkages of the $N$-acetylD-glucosamine polymer chitin, a component of fungal cell walls and exoskeleton of insects. It is thought that chitinase in plants functions as a defense against pathogenic attacks (Cohen-Kupiec and Chet, 1998). Recent evidence has shown that chitinase production by plants can be induced by pathogenic attack, but also by abiotic stimuli, including temperature, suggesting that additional functions of chitinases may involve general stress responses and growth and development processes (Kasprzewska, 2003). 
Heat shock proteins are produced by most eukaryotic cells as a response to supra-optimal high temperature (Lindquist and Craig, 1988) or chemical stress (Baniwal et al., 2004). In general, HSPs act as molecular chaperones assisting in protein folding or unfolding for intracellular distribution, assembly, and degradation to maintain protein homeostasis, to normalize protein functions, and to protect cells from stress damages (Baniwal et al., 2004). There are five classes of HSPs based on their molecular weight: HSP100, HSP90, HSP70, HSP60, and low molecular weight HSPs (smHSPs) (Iba, 2002). Among them, the functions of smHSPs are the least understood. Their function might be to maintain cell structure during stress, to sequester translationally inactive mRNA during stress, or they might have an enzymatic activity that has yet to be identified (Helm et al., 1993). In soybean, HSP22 belongs to smHSPs, but it is located in mitochondria, unlike other smHSPs (Helm et al., 1993; Lenne and Douce, 1994). Helm et al. (1993) reported that HSP22 was induced by heat stress, but also by desiccation in maturing seed embryos. Stupnikova et al. (2006) demonstrated the function of HSP22 in protecting mitochondrial activity to cold or high temperature in maturing seed embryos. In tobacco (Nicotiana tabacum L.) the expression of HSP genes was associated with the improvement of seed vigor (Prieto-Dapena et al., 2006). We observed an increased accumulation of HSP22 in seeds developed under the high temperature treatment relative to seeds from the control temperature regime, indicating that soybean seeds increase their constitutive levels of HSPs including HSP22 as protection from damaging effects of high temperature. Although the increased HSP22 levels we observed in seeds developed under the high temperature treatment may have afforded some protection it was not sufficient to fully counter high temperature damage because that seed exhibited a significantly lower germination percentage than control seed.

We detected an increased accumulation of an EM protein in seeds developed under the high temperature treatment relative to seeds from the control temperature regime. The EM proteins in soybean represent late embryogenesis abundant (LEA) proteins. The LEA proteins exist widely in plant seeds and are synthesized in abundance, as their name suggests, during late embryo development (Bewley and Black, 1994). The LEA genes have been cloned from many plant species and at least seven different groups of LEA proteins have been defined on the basis of expression pattern and sequence (Zhang et al., 2000). The expression of LEA proteins is linked to the acquisition of desiccation tolerance in seeds, suggesting they are induced by desiccation and play roles in the protection of cell structure damage against water loss. Imai et al. (1996) suggest that LEA proteins have a role in protection of cells from damage of salt and freeze stresses. Many LEA proteins have been discovered in soybean (Liu and Zheng, 2005; Porcel et al., 2005; Shih et al., 2004; Soulages et al., 2003; Zhang et al., 2000), but no relationships between LEA protein accumulation to high temperature stress have been reported. The EM protein identified in this study, based on the protein sequence similarity, is likely to be a Sle 2 or Sle3 (two of the five LEA protein genes) gene product (Calvo et al., 1997) of group 1 LEA proteins.

Bowman-Birk proteinase inhibitors were discovered first in soybean seeds (Birk, 1985). Proteinase inhibitors temporally and spatially regulate the initiation of proteolysis during germination (Mayer and Shain, 1974). The function of BBIs has been proposed to include the storage of sulfur amino acids during dormancy and protection against insects and microorganisms (Deshimaru et al., 2004). We detected an increase in Bowman-Birk type proteinase inhibitor D, one of five BBIs identified to date (Deshimaru et al., 2004), in seeds developed under the high temperature treatment relative to seeds from the control temperature regime. However, the relationship of this proteinase inhibitor to high temperature stress and seed germination has not been reported. We assume that the inhibition of proteinase activities by BBIs during seed germination changes the balance of functional enzyme activities and the availability of nitrogen supply for seedling growth, resulting in decrease of seedling vigor. We recognize that this assumption needs the support of additional experimentation.

In conclusion, we observed changes in seed composition, vigor, and proteome in mature dry soybean seeds developed under a high temperature treatment $\left(37 / 30^{\circ} \mathrm{C}\right.$ day/night) relative to seeds from the control temperature regime $\left(27 / 18^{\circ} \mathrm{C}\right.$ day/night). First, high temperature during seed development increased the concentrations of palmitic, stearic, and oleic acids and decreased the concentrations of linoleic and linolenic acids and the combined sugars. However, our proteomic study did not uncover the proteins whose expressions are associated with the noted changes in seed composition, except for SBP. Compositional changes occurred during seed development while the genes or proteins attributed to the changes were expressed transiently during seed development, but not accumulated in mature dry seeds. To investigate the genes or proteins attributed to the seed composition changes by high temperature treatment, we need to study the transient proteomic changes after a certain time (e.g., 1, 2, and/or 5 d) exposure to high temperature treatment. Second, the decrease in seed vigor due to high temperature treatment in this research could be explained by (i) damaged integrity of cellular membranes, (ii) changes in accumulation of some functional proteins, and (iii) possible changes in protein activity. We observed increased electrical conductivity, indicating greater electrolyte leakage due to damaged cellular membranes. In addition to the possibility of high temperature stress reducing membrane integrity, proteomic analysis shows that several functional proteins that may be associated with decreased seed vigor were differentially accumulated in mature dry seeds after treatment with high temperature, including 
SBP, FDH, HSP22, EM, chitinase, and BBI. However, the relationships between seed vigor and these functional proteins are unclear and further investigations are needed before exploiting the mechanisms underlying seed vigor loss caused by high temperature during seed development.

\section{Acknowledgments}

We thank April Bailey and Paul Little for their technical assistance. We also acknowledge the services of and helpful discussions with the staff of the Charles W. Gehrke Proteomics Center at the University of Missouri (Beverly DaGue, Nathan Oehrle, and Brian Mooney). We are grateful for the advice and consultation provided by statisticians Drs. Athanasios Micheas, Baohong Guo, and Mark Ellersieck of the University of Missouri.

\section{References}

Abdus, S., and P.B. Goodwin. 1980. Seed vigor in bean (Phaseolus vulgaris L. cv. Apollo) as influenced by temperature and water regime during development and maturation. J. Exp. Bot. 31:313-323.

Abrahamsen, M., and T.W. Sudia. 1966. Studies on the soluble carbohydrates and carbohydrate precursors in germinating soybean seed. Am. J. Bot. 53:108-114.

Association of Official Seed Analysts. 2002. Seed vigor testing handbook. AOSA, Beltsville, MD.

Baker, J.T., L.H. Allen, Jr., K.J. Boote, Jr., and J.W. Jones. 1989. Response of soybean to air temperature and carbon dioxide concentration. Crop Sci. 29:98-105.

Baniwal, S.K., K. Bharti, K.Y. Chan, M. Fauth, A. Ganguli, S. Kotak, S.K. Mishra, L. Nover, M. Port, K.-D. Scharf, J. Tripp, D. Zielinski, and P. von Koskull-Döring. 2004. Heat stress response in plants: A complex game with chaperones and more than 20 heat stress transcription factors. J. Biosci. 29:471-487.

Bewley, J.D., and M. Black. 1994. Seeds: Physiology of development and germination. 2nd ed. Plenum, New York.

Bilyeu, K.D., P. Zeng, P. Coello, Z.J. Zhang, H.B. Krishnan, A. Bailey, P.R. Beuselinck, and J.C. Polacco. 2008. Quantitative conversion of phytate to inorganic phosphorus in soybean seeds expressing a bacterial phytase. Plant Physiol. 146:468-477.

Birk, Y. 1985. The Bowman-Birk inhibitor: Trypsin- and chymotrypsin-inhibitor from soybeans. Int. J. Pept. Protein Res. 25:113-131.

Breene, W.M., S. Lin, L. Hardman, and J. Orf. 1988. Protein and oil content of soybeans from different geographic locations. J. Am. Oil Chem. Soc. 65:1927-1931.

Burton, J.W. 1987. Quantitative genetics: Results relevant to soybean breeding. In J.R. Wilcox (ed.) Soybeans: Improvement, production, and uses. 2nd ed. ASA, CSSA, and SSSA, Madison, WI.

Burton, J.W., R.F. Wilson, W.P. Novitzky, G.J. Rebetzke, and V.P. Pantalone. 2006. Registration of N98-4445A mid-oleic soybean germplasm line. Crop Sci. 46:1010-1012.

Calvo, E.S., E.S. Wartle, and R.C. Shoemaker. 1997. Cloning, mapping, and analyses of expression of the Em-like gene family in soybean [Glycine max L. Merr.]. Theor. Appl. Genet. 94:957-967.

Carver, B.F., J.W. Burton, T.E. Carter, Jr., and R.F. Wilson. 1986. Response to environmental variation of soybean lines selected for altered unsaturated fatty acid composition. Crop Sci. 26:1176-1180.
Chen, Q.C., and B.W. Li. 2003. Separation of phytic acid and other related inositol phosphates by high-performance ion chromatography and its applications. J. Chromatogr. 1018:41-52.

Cohen-Kupiec, R., and I. Chet. 1998. The molecular biology of chitin digestion. Curr. Opin. Biotechnol. 9:270-277.

Colete, J.C.F., R.D. Vieira, and A.S. Dutra. 2004. Electrical conductivity and soybean seedling emergence. Sci. Agric. 61:386-391.

Davy de Virville, J., C. Cantrel, A.L. Bousquet, M. Hoffelt, A.M. Tenreiro, V. Vaz Pinto, J.D. Arrabacxa, O. Caiveau, F. Moreau, and A. Zachowski. 2002. Homeoviscous and functional adaptations of mitochondrial membranes to growth temperature in soybean seedlings. Plant Cell Environ. 25:1289-1297.

Deshimaru, M., S. Yoshimi, S. Shioi, and S. Terada. 2004. Multigene family for Bowman-Birk type proteinase inhibitors of wild soja and soybean: The presence of two BBI-A genes and pseudogenes. Biosci. Biotechnol. Biochem. 68:1279-1286.

Dornbos, D.L. 1995. Production environment and seed quality. p. 119-149. In A.S. Basra (ed.) Seed quality: Basic mechanisms and agricultural implications. Food Products Press, New York.

Dornbos, D.L.J., and R.E. Mullen. 1991. Influence of stress during soybean seed fill on seed weight, germination and seedling growth rate. Can. J. Plant Sci. 35:373-383.

Dornbos, D.L., and R.E. Mullen. 1992. Soybean seed protein and oil contents and fatty acid composition adjustments by drought and temperature. J. Am. Oil Chem. Soc. 69:228-231.

Dornbos, D.L., R.E. Mullen, and E.G. Hammond. 1989. Phospholipids of environmentally stressed soybean seeds. J. Am. Oil Chem. Soc. 66:1371-1373.

Egli, D.B., and D.M. TeKrony. 1995. Soybean seed germination, vigor, and field emergence. Seed Sci. Technol. 23:595-607.

Egli, D.B., D.M. TeKrony, J.J. Heitholt, and J. Rupe. 2005. Air temperature during seed filling and soybean seed germination and vigor. Crop Sci. 45:1329-1335.

Egli, D.B., and I.F. Wardlaw. 1980. Temperature response of seed growth characteristics of soybean. Agron. J. 72:560-564.

Fehr, W.R., C.E. Caviness, D.T. Burmood, and J.S. Pennington. 1971. Stage of development descriptions for soybean, Glycine $\max ($ L.) Merrill. Crop Sci. 11:929-931.

Fernandez-Moya, V., E. Martinez-Force, and R. Garces. 2003. Temperature-related non-homogeneous fatty acid desaturation in sunflower (Helianthus annuus L.) seeds. Planta 216:834-840.

Gibson, L.R., and R.E. Mullen. 1996. Soybean seed composition under high day and night growth temperatures. J. Am. Oil Chem. Soc. 73:733-737.

Grimes, H.D., P.J. Overvoorde, K. Ripp, V.R. Franceschi, and W.D. Hitz. 1992. A $62-\mathrm{kD}$ sucrose binding protein is expressed and localized in tissues actively engaged in sucrose transport. Plant Cell 4:1561-1574.

Gusta, L.V., E.N. Johnson, N.T. Nesbitt, and K.J. Kirkland. 2004. Effect of seeding date on canola seed quality and seed vigor. Can. J. Plant Sci. 84:463-471.

Hamman, B., H. Halmajan, and D.B. Egli. 2001. Single seed conductivity and seedling emergence in soybean. Seed Sci. Technol. 29:575-586.

Havli, J., H. Thomas, M. Sebela, and A. Shevchenko. 2003. Fastresponse proteomics by accelerated In-gel digestion of proteins. Anal. Chem. 75:1300-1306.

Hellman, U., C. Wernstedt, J. Góñez, and C.-H. Heldin. 1995. Improvement of an 'In-gel' digestion procedure for the micropreparation of internal protein fragments for amino acid sequencing. Anal. Biochem. 224:451-455. 
Helm, K.W., P.R. LaFayette, R.T. Nagao, J.L. Key, and E. Vierling. 1993. Localization of small heat-shock proteins to the higherplant endomembrane system. Mol. Cell. Biol. 13:238-247.

Heppard, E.P., A.J. Kinney, K.L. Stecca, and G.H. Miao. 1996. Developmental and growth temperature regulation of two different microsomal omega-6 desaturase genes in soybeans. Plant Physiol. 110:311-319.

Hourton-Cabassa, C., F. Ambard-Bretteville, F. Moreau, J.D. de Virville, R. Remy, and C.C. des Francs-Small. 1998. Stress induction of mitochondrial formate dehydrogenase in potato leaves. Plant Physiol. 116:627-635.

Hurburgh, C.R., T.J. Brumm, Jr., J.M. Guinn, and R.A. Hartwig. 1990. Protein and oil patterns in US and world soybean markets. J. Am. Oil Chem. Soc. 67:966-973.

Hymowitz, T., F.I. Collins, J. Panczar, and W.M. Walker. 1972. Relationship between the content of oil, protein and sugar in soybean seed. Agron. J. 64:613-616.

Iba, K. 2002. Acclimative response to temperature stress in higher plants: Approaches of gene engineering for temperature tolerance. Annu. Rev. Plant Biol. 53:225-245.

Imai, R., L. Chang, A. Ohta, E.A. Bray, and M. Takagi. 1996. A lea-class gene of tomato confers salt and freezing tolerance when expressed in Saccharomyces cerevisiae. Gene 170:243-248.

Kane, M.V., C.C. Steele, L.J. Grabau, C.T. MacKown, and F.D. Hildebrand. 1997. Early- maturing soybean cropping system: III. Protein and oil contents and oil composition. Agron. J. 89:464-469.

Kasprzewska, A. 2003. Plant chitinases: Regulation and function. Cell. Mol. Biol. Lett. 8:809-824.

Keigley, P.J., and R.E. Mullen. 1986. Changes in soybean seed quality from high temperature during seed fill and maturation. Crop Sci. 26:1212-1216.

Keirstead, C.H. 1952. Marketing study of factors affecting the quantity and value of products obtained from soybeans. USDA Production and Marketing Administration, Washington, DC.

Lenne, C., and R. Douce. 1994. A low molecular mass heat-shock protein is localized to higher plant mitochondria. Plant Physiol. 105:1255-1261.

Lindquist, S., and E.A. Craig. 1988. The heat shock proteins. Annu. Rev. Genet. 22:631-677.

Liu, Y., and Y. Zheng. 2005. PM2, a group 3 LEA protein from soybean, and its 22-mer repeating region confer salt tolerance in Escherichia coli. Biochem. Biophys. Res. Commun. 331:325-332.

Lowell, C.A., and T.M. Kuo. 1989. Oligosaccharde metabolism and accumulation in developing soybean seeds. Crop Sci. 29:459-465.

Lott, J.N.A., J.S. Greenwood, and G.D. Batten. 1995. Mechanisms and regulation of mineral nutrient storage during seed development. p. 215-235. In J. Kigel and G. Galili (ed.) Seed development and germination. Marcel Dekker, New York.

Loewus, F.A. 1990. Structure and occurrence of inositols in plants. p. 1-11. In D.J. Morre, W.F. Boss, and F.A. Loewus (ed.) Inositol metabolism in plants. Wiley-Liss, New York.

Mayer, A.M., and Y. Shain. 1974. Control of seed germination. Annu. Rev. Plant Physiol. 25:167-193.

McAlister, D.F., and O.A. Krober. 1958. Response of soybeans to leaf and pod removal. Agron. J. 50:674-677.

Medeiros, J.S. 1982. Characterization of the subunits of beta-conglycinin, and application of the enzyme-linked immunosorbent assay (ELISA) to the determination of the contents of beta-conglycinin and glycinin in soybean (Glycine max (L.)
Merrill) seeds. Ph.D. diss. Purdue Univ., West Lafayette, IN. Medzihradszky, K.F., J.M. Campbell, M.A. Baldwin, A.M. Falick, P. Juhasz, M.L. Vestal, and A.L. Burlingame. 2000. The characteristics of peptide collision-induced dissociation using a high-performance MALDI-TOF/TOF tandem mass spectrometer. Anal. Chem. 72:552-558.

Miceli, F., S.J. Crafts-Brandner, and D.B. Egli. 1995. Physical restriction of pod growth alters development of soybean plants. Crop Sci. 35:1080-1085.

Mooney, B.P., and J.J. Thelen. 2004. High-throughput peptide mass fingerprinting of soybean seed proteins: Automated workflow and utility of UniGene expressed sequence tag databases for protein identification. Phytochemistry 65:1733-1744.

Nagao, R.T., Y.R.J. Lee, P.R. LaFayette, V.H. Goekjian, K. O'Grady, and J.L. Key. 1995. Analysis of multiple classes of soybean heat shock genes and proteins. p. 3-20. Physical stresses in plants: Genes and their products for tolerance. In Biochemical and Cellular Mechanisms of Stress Tolerance in Plants: Proc. of the NATO Advanced Research Workshop, Maratea, Italy. 20-24 June 1994. Springer-Verlag, Berlin.

Nielsen, N.C., and Y.W. Nam. 1999. Soybean globulins. p. 285313. In P.R. Shewry and R. Casey (ed.) Seed proteins. Kluwer Academic, Dordrecht, the Netherlands.

Obendorf, R.L., M. Horbowicz, A.M. Dickerman, P. Brenac, and M.E. Smith. 1998. Soluble oligosaccharides and galactosyl cyclitols in maturing soybean seeds in planta and in vitro. Crop Sci. 38:78-84.

Oliver, D.J. 1981. Formate oxidation and oxygen reduction by leaf mitochondria. Plant Physiol. 68:703-705.

Openshaw, S.J., H.H. Hadley, and C.E. Brokoski. 1979. Effect of pod removal upon seeds of nodulating and nonnodulating soybean lines. Crop Sci. 19:289-290.

Pedersen, P. 2004. Soybean growth and development. Iowa State Univ. Ext. Pub. PM1945. Iowa State Univ., Ames.

Peterbauer, T., L.B. Lahuta, A. Blöchl, J. Mucha, D.A. Jones, C.L. Hedley, R.J. Gòrecki, and A. Richter. 2001. Analysis of the raffinose family oligosaccharide pathway in pea seeds with contrasting carbohydrate composition. Plant Physiol. 127:1764-1772.

Piper, E.L., and K.J. Boote. 1999. Temperature and cultivar effects on soybean seed oil and protein concentrations. J. Am. Oil Chem. Soc. 76:1233-1241.

Porcel, R., R. Azcon, and J.M. Ruiz-Lozano. 2005. Evaluation of the role of genes encoding for dehydrin proteins (LEA D-11) during drought stress in arbuscular mycorrhizal, Glycine max and Lactuca sativa plants. J. Exp. Bot. 56:1933-1942.

Prieto-Dapena, P., R. Castano, C. Almoguera, and J. Jordano. 2006. Improved resistance to controlled deterioration in transgenic seeds. Plant Physiol. 142:1102-1112.

Rebetzke, G.J., V.R. Pantalone, J.W. Burton, B.F. Carver, and R.F. Wilson. 1996. Phenotypic variation for saturated fatty acid content in soybean. Euphytica 91:281-295.

Roberts, C.A., C.W. Ren, H.R. Benedict, K.D. Bilyeu, and P.R. Beuselinck. 2006. Fatty acid profiling in soybean cotyledons by NIR spectroscopy. Appl. Spectrosc. 60:1328-1333.

Rosner, B. 2006. Fundamentals of biostatistics. 6th ed. Thomson Brooks/Cole, Belmont, CA.

Sinensky, M. 1974. Homeoviscous adaptation: A homeostatic process that regulates the viscosity of membrane lipids in Escherichia coli. Proc. Natl. Acad. Sci. USA 71:522-525.

Shih, M.D., S.C. Lin, J.S. Hsieh, C.H. Tsou, T.Y. Chow, T.P. Lin, and Y.I. Hsing. 2004. Gene cloning and characterization of a 
soybean (Glycine max L.) LEA protein, GmPM16. Plant Mol. Biol. 56:689-703.

Smirnov, I.P., X. Zhu, T. Taylor, Y. Huang, P. Ross, I.A. Papayanopoulos, S.A. Martin, and D.J. Pappin. 2004. Suppression of r-cyano-4-hydroxycinnamic acid matrix clusters and reduction of chemical noise in MALDI-TOF mass spectrometry. Anal. Chem. 76:2958-2965.

Soulages, J.L., K. Kim, E.L. Arrese, C. Walters, and J.C. Cushman. 2003. Conformation of a group 2 late embryogenesis abundant protein from soybean: Evidence of poly (L-proline)type II structure. Plant Physiol. 131:963-975.

Spears, J.F., M. Sun, J.W. Burton, T.G. Isleib, and D.L. Jordan. 2005. Influence of temperature during seed development on higholeate soybean and peanut seed quality. In ASA, CSSA, SSSA Annu. Meet., Salt Lake City, UT. 6 -10 Nov. 2005. Available at http://a-c-s.confex.com/crops/2005am/techprogram/P2076. HTM (verified 2 Feb. 2009). ASA, CSSA, SSSA, Madison, WI.

Spears, J.F., D.M. TeKrony, and D.B. Egli. 1997. Temperature during seed filling and soybean seed germination and vigour. Seed Sci. Technol. 25:233-244.

Steere, W.C., W.C. Levengood, and J.M. Bondie. 1981. An electronic analyzer for evaluating seed germination and vigor. Seed Sci. Technol. 9:567-576.

Stupnikova, I., A. Benamar, D. Tolleter, J. Grelet, G. Borovskii, A.-J. Dorne, and D. Macherel. 2006. Pea seed mitochondria are endowed with a remarkable tolerance to extreme physiological temperature. Plant Physiol. 140:326-335.

Taiz, L., and E. Zeiger. 1998. Plant physiology. 2nd ed. Sinauer Associates, Sunderland, MA.

TeKrony, D.M., D.B. Egli, and J.L. Spear. 2000. Seed quality and the early soybean production system. p. 45-57. In Proc. 30th Soybean Seed Research Conf., Chicago, IL. 6-8 Dec, 2000. American Seed Trade Assoc., Alexandra, VA.

TeKrony, D.M., L.J. Grabau, M. DeLacy, and M. Kane. 1996. Early planting of early-maturing soybean: Effects on seed germination and Phomopsis infection. Agron. J. 88:428-433.
Thomas, J.M.G., K.J. Boote, L.H. Allen, Jr., M. Gallo-Meagher, and J.M. Davis. 2003. Elevated temperature and carbon dioxide effects on soybean seed composition and transcript abundance. Crop Sci. 43:1548-1557.

Tishkov, V.I., and V.O. Popov. 2004. Catalytic mechanism and application of formate dehydrogenase. Biochemistry 69:1252-1267.

Vieira, R.D., J.A. Paiva Aguero, and D. Perecin. 1999. Electrical conductivity and field performance of soybean seeds. Seed Technol. 21:15-24.

Wan, J., M. Torres, A. Ganapathy, J. Thelen, B.B. DaGue, B. Mooney, D. Xu, and G. Stacey. 2005. Proteomic analysis of soybean root hairs after infection by Bradyrhizobium japonicum. Mol. Plant Microbe Interact. 18:458-467.

Watanabe, I., and T. Nagasawa. 1990. Appearance and chemical composition of soybean seeds in germplasm collection of Japan: II. Correlation among protein, lipid and carbohydrate percentage. Jpn. J. Crop. Sci. 59:661-666.

Wilson, R.F. 2004. Seed composition. p. 521-677. In H.R. Boerma and J.E. Specht (ed.) Soybeans: Improvement, production, and uses. 3rd ed. ASA, CSSA, SSSA, Madison, WI.

Wolf, R.B., J.F. Cavins, R. Kleiman, and L.T. Black. 1982. Effect of temperature on soybean seed constituents: Oil, protein, moisture, fatty acids, amino acid, and sugars. J. Am. Oil Chem. Soc. 59:230-232.

Yeboah, N.A., M. Arahira, V.H. Nong, D. Zhang, K. Kadokura, A. Watanabe, and C. Fukazawa. 1998. A class III acidic endochitinase is specifically expressed in the developing seeds of soybean (Glycine max [L.] Merr.). Plant Mol. Biol. 36:407-415.

Zanakis, G.N., R.H. Ellis, and R.J. Summerfield. 1994. A comparison of changes in vigor among three genotypes of soybean (Glycine max) during seed development and maturation in three temperature regimes. Exp. Agric. 30:157-170.

Zhang, L., A. Ohta, M. Takagi, and R. Imai. 2000. Expression of plant group 2 and group 3 LEA genes in Saccharomyces cerevisiae revealed functional divergence among LEA proteins. J. Biochem. (Tokyo) 127:611-616. 